\title{
Leading Change with the Heart: Exploring the Relationship between Emotional Intelligence and Transformational Leadership in the Era of Covid-19 Pandemic Challenges
}

\author{
Carlton Brown ${ }^{1}$, Uzoechi Nwagbara ${ }^{2 *}$ \\ ${ }^{1}$ Management Consultant, Associate Lecturer, London School of Business \& Finance, 2 Bunhill Row, \\ London, EC1Y 8HQ, United Kingdom \\ ${ }^{2}$ Associate Lecturer, University of Sunderland in London, 197 Marsh Wall, Isle of Dogs, London, E14 \\ 9SG, United Kingdom; Professor of management, ICT University, Messassi, Zoatupsi, Yaoundé, \\ Cameroon \\ e-mail: uzoechin@yahoo.com
}

DOI: 10.51865/EITC.2021.03.01

\begin{abstract}
In recent decades, effective leadership theorising, perceptions and studies have shifted attention to interpersonal skills and the leader's capacity to inspire, encourage and motivate subordinates as well as create and maintain a sense of positive contribution to the whole of the organisation. This conceptualisation is in sharp contrast to prior studies and conceptualisations resonating with controlling, planning and target-oriented leadership. Consequently, this article takes as its premise the relationship between emotional intelligence (leading with the heart) and transformational leadership within the purview of COVID-19 (coronavirus) pandemic challenges. It is thus argued here that in times of crisis that humanity (and the organisation specifically) is faced with at the moment unleashed by COVID-19 pandemic challenges, a style of leadership that takes as its focal point emotional intelligence mediated by transformational leadership can be instrumental in leading business organisation through this epoch. The methodology used here is steeped in cursory look at prior, relevant literature on these phenomena and how it helps to inform a conceptual framework that could help in shedding new light on how to confront the challenges of Covid-19 through effective leadership. This paper concludes that in times of crisis particularly the one ushered in by Covid-19 - a medley of emotional intelligence and transformational leadership is necessary to drive effective change for organisation, which would help them to bounce back and operate profitably and sustainably.
\end{abstract}

Keywords: emotional intelligence; transformational leadership; leading change; COVID-19 pandemic challenges.

JEL Classification: M12; M30; D83.

\footnotetext{
${ }^{*}$ Corresponding author
} 


\section{Introduction}

COVID-19 (coronavirus) pandemic has been described as a form of epic test of leadership style, character and strategy of business leaders/managers for many organisations and people globally (WHO, 2020; Sahu, 2020). Great business leaders have initiated varying leadership styles and strategies aimed at confronting the impact of the pandemic in order to reset their existence (McKinsey, 2020), business survival (Sahu, 2020) and competitive advantage in the ever increasing competitive business environment, ushered in by the coronavirus (UNESCO, 2020). In consonance with this context, the preoccupation of this paper is to shed light on how leading with the heart - medley of emotional intelligence and transformational leadership - can help in mobilising a form of organisational leadership, which could aid organisations to triumph the challenges of COVID-19 challenges.

In December 2019, a new form of coronavirus emerged in Wuhan, China and quickly spread globally to several other countries, which has become a threat to business and public health around the globe (WHO, 2020). Within weeks, the World Health Organisation (WHO) described the virus a global pandemic, urging all countries to take necessary and urgent stapes to reduce the spread of the disease, viral contamination and reduction in fatalities. Globally, this pandemic has triggered great economic, social and business disruption for organisations, governments and citizens. Consequently, governments set up measures and legislation to protect people's lives as well as related public health rules and restrictions. In reducing the risk of viral spread, government have asked people to isolate, work from home and apply strict social distance rules. Thus, the pandemic has impacted on most facets of people's lives around the world including 'lock-down' measures forcing institutions, organisations and business to close (Sahu, 2020; UNESCO, 2020). This paper sheds light on the impacts of this pandemic to businesses and how business leadership style can help in confronting the challenges posed by the coronavirus. This paper argues that transformational leadership embedded in emotional intelligence could be instrumental in leading businesses successfully in these organisational murky waters (McKinsey, 2020).

This paper focuses on identifying traits and facets of leadership style and/or behaviour, which constitute the essentials for effective leadership roles and styles necessary for confronting the dangers and challenges stemming from the pandemic in order to sustain businesses, motivate workers and achieve profit as businesses are ineluctably encumbered by the bangs and pangs of Covid-19. This paper thus contends that transformational leadership behaviours constitute an emotion-based method, which is aimed at widening and elevating subordinate interests beyond the self (Goleman, 1995). This approach is in agreement with the accomplishment of group tasks and organisational goals generating subordinates' acceptance, collaboration and awareness (Goleman 2006; 1995; Yammarino and Bass, 1990). Specifically, this paper is founded on the premise of understanding the effects of emotional intelligence on transformational leadership leading to greater engagement, motivation, and participation. Whilst leadership is multifaceted, the fundamental underpinnings are to nurture and develop positive feelings within the people that they lead (Kotter, 1990).

\section{The Notion of Leadership}

First of all, leadership is a contested notion - this entails that there is no consensus on its meaning (Nwagbara, 2012; Bennis \& Nanus, 2004). Nevertheless, Kotter (1990) argues that leadership is the process of motivating, influencing, empowering and mobilising people or a group to act without being forced or coerced (Rost, 1991). Northouse (2007) stresses that it is the capacity to elicit what (Kotter, 1990, p. 62) describes as "energy surge" propelling people or subordinates to as without coercion as well as galvanising them to act in order to achieve a stated goal (Rost, 1991). It is within this purview that Northouse (2007) considers leadership as 
a process of inspiring, encouraging and influencing people (workers and specifically nonmanagerial members of staff) to work in concert to realise shared goals and objectives in the organisation. Within the remit of this paper, leadership can be explained as the capacity of a leader to propel a set of internal stimuli, which can enable people to believe in his/her aspiration, goal and/or objectives that are fundamentally important in achieving organisational aim (Bennis \& Nanus, 2004).

\section{Leadership styles and conceptualisations}

As noted in the literature, there are three main styles/categorisations of leadership including autocratic, democratic and laissez faire leadership (Davis \& Ryder, 2016; Northouse, 2007). Democratic leadership empower, motivates and seeks all and sundry inputs in organisational decision-making; while autocratic leadership advocates despotic and exclusive form of leadership. Finally, laissez fair style deals with delegating authority to subordinates for mutual inputs and empowerment (Northouse, 2007). Nevertheless, these leadership styles are not the same thing as leadership theories. The former explains various ways of classifying leadership types and or styles while the latter deals with various ways of conceptualising or interpreting leadership styles (Bennis \& Nanus, 2004; Bass, 1985; Burns, 1978). Key leadership theories involve great man, trait, situational, transactional, transformational, behavioural, participative, and contingency theory. Given the remit of this paper, exhaustive explanation of leadership styles and theories is not provided (see Kotter, 1990 for more details). This article has adopted a position, which will consider and analyse leadership from two distinct polarised perspectives, transactional leadership and transformational leadership style, as they continue to be topics of debate in the literature (Bass, 1985).

Leaders may adopt a multidimensional and paradoxical approach which may utilise both transactional and transformational leadership behaviours. Bass (1985) posits that the transactional and transformational leadership paradigms are complementary constructs rather than opposites and they have a symbiotic interdependency relationship; although there are instances when they could be considered as opposites (Northouse, 2007). Both leadership styles have the desired objectives of delivering positive achievements and outcomes for their organisation (Bass, 1985). Numerous studies have looked at leadership and have specifically contrasted transactional leadership with transformational leadership (Ogbonna \& Harris, 2000). Transactional leaders focus on transactional and exchange relationship with their subordinates, where reward and punishment are the prime objective (Bass \& Avolio, 1993). In contrast, transformational leaders are considered as visionary and enthusiastic, with an inherent ability to motivate, engage and influence subordinates (Brown 2014; Howell \& Avolio, 1993). There is an intrinsic conflict within the literature, transactional and transformational leadership are uniquely different, however, their traits can be correspondingly displayed and co-exist within the same leader (Mackenzie, Rich \& Podsakoff 2001).

\section{Transactional leadership}

Transactional leaders will often set clear specific goals, and articulate the performance expectations and the desired outcomes and the consequential potential rewards for subordinates' efforts and they will ensure that they offer constructive feedback to keep their subordinates on task (Bass \& Avolio, 1993). The term transactional denotes to receive something in exchange for something else or commonly referred to as contingent-reward system and the functional management by exception (Avolio, Bass \& Jung, 1999). Transactional leaders are also renowned for their need for subordinate compliance of policies, procedures and rules (Bass \& Avolio, 1993). The dynamic relationship between a transactional leadership style and a follower is one of exchange; this is where there is an implicit or explicit offer of exchange between the manager and employee and a promise of reward in return for good performance (Bass, 1985) or something of value (Humphreys 2002). This symbiotic relationship and contribution required by 
each party are both understood and compensated (Burns, 1978). Transactional leaders have a propensity to operate well within existing structures as they seek to strengthen those structures, plans, culture, and strategic outcomes (Vera \& Crossan, 2004).

\section{Transformational leadership}

In contrast, the transformational leader is considered charismatic and someone who has a strong emphasis on emotions and values (Yukl, 1994). This leadership conceptualisation shares a lot in common with emotional intelligence (Goleman, 2006). Transformational leaders have the propensity to influence individuals to transcend their self-interest and beliefs for the benefit of the bigger vision of the organisation (Vera \& Crossan, 2004); they are also considered as captivating; intellectually stimulating and inspirational as they engage their followers using visionary skills and their ability to be individually considerate (Avolio et. 1999). Channer \& Hope (2001) have described transformational leaders as leading others through inspiration and enthusiasm, deviating from ordering and instructing as well as planning and controlling. Humphreys (2002) contends that transformational leaders are respected, admired, and trusted by their subordinates. Other scholars have continued to highlight the noteworthy attributes of the transformational leader and their capacity to create organisational environments where their followers perform "beyond expectations" (Fetter, Mackenzie, Moorman \& Podsakoff, 1990; Burns, 1978; House \& Shamir, 1993; Bass 1985) as they inspire others with their vision and engender excitement through their enthusiasm (Bass \& Avolio, 1990).

The workplace environment is described and considered competitive, demanding and where employees are required to perform and deliver specific outcomes at agreed levels. A recent analysis of over 7,939 business units in 38 companies examined the nexus at the business-unit level between employee satisfaction and engagement and the business-unit outcomes of productivity, employee turnover, and accidents (Harter \& Schmidt, 2002). The findings further show that leadership style and managing emotions are central to successful entrepreneurship. The quest to deliver results can quite often be very demanding, which can result in a negative emotional response. An employee's role and subsequent performance will have inherent degrees of stress and consequently, there is greater susceptibility that they will encounter substantial emotional demands (Chonko, Howell \& Bellinger, 1986). Cherniss (2000) posits that where the pace of change in an organisation continues to be amplified, for example the coronavirus pandemic challenges for organisations, the expectations and demands placed upon their employees' cognitive and emotional resources become compounded triggering a form of leadership that can help lead change effectively (McKinsey, 2020).

The overarching synopsis suggests that in time of critical organisational moments (Covid-19 challenges) the contingent reward leadership behaviour, which is closely aligned with transactional leadership, becomes ineffective style of leadership when compared to the transformational approach, which is democratic and empowering (Kotter, 1990). Democratic leadership has commonalities with the transformational leadership, underpinned by the attributes that are present within idealised influence behaviour variable, alongside intellectual stimulation, intellectual stimulation and inspirational motivation, which are consistent with transformational leadership (Bass, 1995). As a consequence, there has been a shift in the attitudes and expectations of the leader-follower relationship and researchers have appealed for a gentler and kinder management style for leading change effectively in time of crisis (Blanchard \& Peale, 1988). London (1999) argues that it is as a consequence of the socioeconomic and technological landscape in which leaders have to operate in the 21 century organisational settings. Extant literature suggests that leaders, who can adopt a more transformational centric leadership style and lead with their hearts will deliver best organisational outcomes, which is fundamentally needed in the present business economic climate engendered by coronavirus pandemic (McKinsey, 2020; Sahu, 2020). 
In fact, Burns (1978) contends that transformational and transactional leadership approaches as opposite. Fundamental to Bass' (1985) conceptualisation of transformational leadership is that transformational leaders are agents of inspiration, commitment, motivation and vision leading to transforming the ideals and behaviours of subordinates (Kotter, 1990). Thus, business leaders have a great role to play in moving their organisations from the perils and dangers of the Covid19 business challenges through leading with their heart and inspiring subordinates to rise above self-interest (Kotter, 1990). In offering further insights into how leaders develop relationship with their followers, leading to transformation, Bass (1985) provided four aspects of transformational leadership that are essential for managing change including organisational change ushered in by Covid-19 (Ruiu, Ragnedda \& Ruiu, 2020).

The first is intellectual stimulation, which espouses that transformational leaders stimulate their followers to be committed, creative and innovative by arousing their imagination, challenging old practices and re-articulating problems, for instance the coronavirus challenge, including rearticulating innovative ways of doing things (Bass, 1985). Such business leaders help to galvanise intellectual participation and engagement of subordinates (Yammarino \& Bass, 1990). Second, inspirational motivation, helps leaders to empower and energise their followers by framing a compelling vision of the organisation (Yukl \& van Fleet, 1992); their behaviour motivates and inspires followers by offering solutions to any challenge leading to effective change. They also build a sense of optimism and enthusiasm. Third, Idealised Influence advocates leaders that exert idealised influence serving as ideal role models for followers (Kotter, 1990). They are charismatic and "walks the talk" triggering a sense of admiration by their followers. Finally, Individualised consideration, is the important facet of transformational leadership Avolio \& Bass, 1991). It can take the forms of negative and/or positive feedback procedures aimed at building and developing followers' confidence and commitment (Podoff, Todor \& Skov, 1982). In this light, Moreover, Fairholm (1998) stresses the significance of transformational leadership in playing crucial roles for leading with the heart in realising organisational vision, values and goals in the current business climate (Ruiu et al., 2020).

\section{Emotional Intelligence}

The notion of emotional intelligence has been influenced by several scholars and academics. However, the general notion of emotional intelligence is partly rooted in Thorndike's (1920) theory of 'social intelligence' and Gardner's (1983) notion of multiple intelligences, especially 'intrapersonal' and 'interpersonal' intelligence performance and behaviour, namely, emotional intelligence (also known as emotional quotient). The term 'emotional intelligence' was first coined by Mayer et al. (1990) when they posited that emotional intelligence was a mental process where previously independent variables (such as thinking and feeling) work in partnership. George (2000) asserts that emotional intelligence is the degree to which emotions are cognitively managed, while Stein (2009) advocates that emotional intelligence is one's ability to synchronise into the world, by being able to connect with others, manage one's outcomes and being aware of other's emotional states. Since the initial conceptualisation by Mayer et al. (1990), there has been an increasing level of emphasis on emotional intelligence (Goleman, 1995). Emotional intelligence is a relatively new notion (Goleman, 2006) that is attracting attention with massive applicability in many organisational areas, such as commitment, performance and job satisfaction (Goleman, 1995).

When Salovey \& Mayer (1990) first coined the term "emotional intelligence", they contextualised it within a framework of a defining set of skills, which they postulate was the antecedent for 'emotional intelligence'. Emotional intelligence has been described as a constellation of emotional self-perceptions located at the lower regions of the personality spectrum (Petrides et al., 2007). However, emotional Intelligence still lacks a universally accepted definition (Zeidner \& Roberts, 2002). Different jobs will often require an adaptable set 
of skills, which sit alongside different degrees of social and emotional participation. Also, distinct professions will also require different types of interpersonal communication (Zeidner, Matthews \& Roberts, 2004).

Employers will frequently recruit employees contingent upon several factors, such as intelligence, perceived competence, personality, experience, and attitudes. These determinants are often considered to be important characteristics regarding supporting the recruitment decision of an employer. According to Cherniss (2000), the pace of change continues to increase and there are greater expectations and demands placed upon a person's cognitive, emotional resources, and as a result, the repertoire of cognitive and emotional instruments will become more applicable in today's socially dynamic environment (Brown, 2014). Thus, the leader's capacity to understand the employee's emotional state and wellbeing will enhance both employer-employees relationship, which manifests into a more conducive work environment. Positive emotions are more likely to be displayed when both the employee and the leader are achieving their organisational goals and objectives in contrast with negative emotions, and this is more likely to occur when the leader has a greater sense of emotional acuity as seen in the Covid-19 era (McKinsey, 2020).

Early scholars (Salovey \& Mayer, 1997) were instrumental in conceptualisation and development of emotional intelligence, however, for this paper, we will examine it through the lens of Goleman (1995). Goleman (2006, 1995) powerfully articulates that emotional intelligence is a prerequisite for successful leadership and it is within the confines of this argumentation that this paper draws its strength and conceptualisation of the notion. The dimensions of emotional intelligence are depicted in Figure 1, which is Emotional Intelligence Competencies illustrating the dimensions (Goleman, 1995) of the schema. Also, see Table 1 for historical rise and development of emotional intelligence.

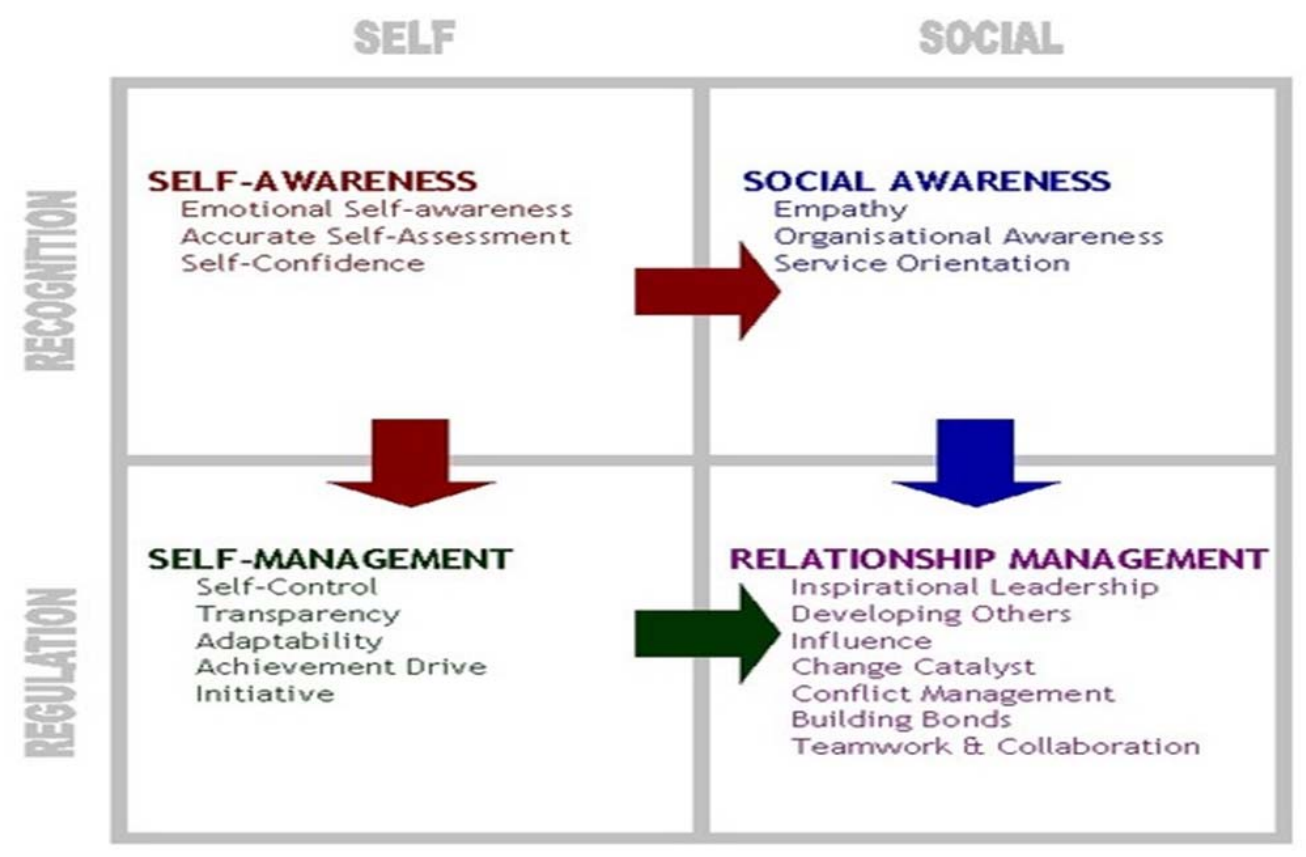

Fig.1: Emotional intelligence framework

Source: Goleman (1995). 
Table 1. Emotional intelligence historical contextualisation

\begin{tabular}{|l|l|l|l|}
\hline $\begin{array}{l}\text { Author and } \\
\text { Year }\end{array}$ & Publication & \multicolumn{1}{c|}{ Topic/Title } & \multicolumn{1}{c|}{ Summary of Findings } \\
\hline $\begin{array}{l}\text { Salovey and } \\
\text { Mayer } \\
(1990)\end{array}$ & $\begin{array}{l}\text { Cognition and } \\
\text { Personality }\end{array}$ & $\begin{array}{l}\text { Emotional } \\
\text { intelligence, } \\
\text { imagination, } \\
\text { cognition, and } \\
\text { personality }\end{array}$ & $\begin{array}{l}\text { Originally described EI as social intelligence. } \\
\text { The capacity to scrutinise the feelings and } \\
\text { emotions of oneself and others, and to utilise } \\
\text { the knowledge to shape one's thinking and } \\
\text { actions. }\end{array}$ \\
\hline $\begin{array}{l}\text { Goleman } \\
(1995)\end{array}$ & $\begin{array}{l}\text { Book, } \\
\text { published by } \\
\text { Bantam Books }\end{array}$ & $\begin{array}{l}\text { Emotional } \\
\text { intelligence }\end{array}$ & $\begin{array}{l}\text { Contended that there are four competencies of } \\
\text { EI: self-awareness, self-management, social } \\
\text { awareness, and relationship management. }\end{array}$ \\
\hline $\begin{array}{l}\text { Bar-On \& } \\
\text { Parker }\end{array}$ & $\begin{array}{l}\text { Technical } \\
\text { manual }\end{array}$ & $\begin{array}{l}\text { Bar-On emotional } \\
\text { quotient inventory: } \\
\text { technical manual, } \\
\text { multi health systems }\end{array}$ & $\begin{array}{l}\text { Identified five components: interpersonal, } \\
\text { intrapersonal, adaptability, stress management, } \\
\text { and general mood components. }\end{array}$ \\
\hline $\begin{array}{l}\text { Weisinger } \\
(1998)\end{array}$ & $\begin{array}{l}\text { Book } \\
\text { published by } \\
\text { Jossey-Bass }\end{array}$ & $\begin{array}{l}\text { Emotional } \\
\text { intelligence at work }\end{array}$ & Review of EI within the workplace. \\
\hline $\begin{array}{l}\text { Mayer \& } \\
\text { Salovey } \\
(1997)\end{array}$ & $\begin{array}{l}\text { Book, } \\
\text { published by } \\
\text { Basic Books. }\end{array}$ & $\begin{array}{l}\text { Emotional } \\
\text { development and } \\
\text { emotional } \\
\text { intelligence, an } \\
\text { implication for } \\
\text { educators }\end{array}$ & $\begin{array}{l}\text { The ability to recognise emotions; to access and } \\
\text { stimulate emotions to generate thought; to } \\
\text { appreciate emotions and EI; the capacity to } \\
\text { regulate emotions to promote emotional and } \\
\text { intellectual growth. }\end{array}$ \\
\hline $\begin{array}{l}\text { Goleman, } \\
\text { D., Boyatzis, } \\
\text { R.E. and } \\
\text { McKee, A., } \\
\text { 2002. }\end{array}$ & $\begin{array}{l}\text { Harvard } \\
\text { Business } \\
\text { Press. }\end{array}$ & $\begin{array}{l}\text { Primal leadership: } \\
\text { Unleashing the power } \\
\text { of emotional } \\
\text { intelligence }\end{array}$ & $\begin{array}{l}\text {.Explores the role of EI in leadership by } \\
\text { revealing that a leader's emotions are } \\
\text { contagious; thus, if a leader resonates positivity, } \\
\text { an organisation thrives; if a leader spreads } \\
\text { negativity, it flounders }\end{array}$ \\
\hline
\end{tabular}

Source: McNaughton \& Zubairi (2014); Goleman (1995).

\section{Self-awareness}

Self-awareness is where emotionally intelligent individuals are cognisant of their emotional states and how they respond and perform in respect of them. They maintain awareness regarding the way they behave (Averill, 1980). The basic tenet of self-awareness is one of selfrecognition; the ability to acknowledge that one's own emotions will either constrain or galvanise one's emotional response but also the emotional responses within others (Goleman et al., 2002). The capacity to maintain a level of acuity is prerequisite, particularly in regards to the leader/follower relationship challenges, as it enables leader/follower to identify, resolve and manage emotional disputes earlier so that they do not become protracted or detracted from the performance objectives of the organisation (Ammeter et al., 2003).

According to Bradberry \& Greaves (2009, pp. 26 ) self-awareness is so critical concerning job performance and it has been noted that eighty-three per cent of people who were high in selfawareness are top performers compared with just two per cent who are bottom performers. Selfaware individuals can influence, change and alter their behaviour and the behaviour of others (George, 2000). Goleman et al. (2002, pp. 40) argue that the most compelling sign of a selfaware individual, are those individuals who take the time to self-reflect and take time to make a decision. Self-awareness is a skill that can be acquired and understanding one's internal emotional triggers is a critical part of that process. The emotional synergy that occurs between the leader and follower who shares that sense of self-awareness, has according to Bradberry \& Greaves (2009, pp. 25), the propensity to achieve stated within the working environment, as they understand the emotional trigger that drives them to achieve. This contention is central to the ability of leader to understand subordinates' emotions and manage them for a successful organisational leadership in the coronavirus pandemic challenges (Morońa \& Biolik-Moron, 2021). 


\section{Self-management}

Polychroniou, (2009) asserts that self-management is one's capacity to keep their emotions subdued, whilst retaining a calm disposition, both internally and outwardly, regardless of the contextual nature or unpredictability of the situation and the social/work setting in which the encounter has occurred. Goleman et al. (2002, pp. 45) contend that our inability to understand one's feelings will prevent an individual from losing control of their emotions. Goleman (1995) also argues that positive emotions such as enthusiasm, excitement and jubilation are agreeable emotional states, juxtaposed to negative emotional states, such as anger, rage and anxiety, as these emotions tend to govern an individual emotional state and these emotions can overwhelm the individual's mental capacity to "focus on the task in hand. Individuals who are effective at self-management will have a greater propensity to sustain a positive and optimistic disposition, and as a consequence, they can have an infectious effect on others (Goleman et al. 2002, pp. 46; Bradberry \& Greaves, 2009, pp. 25). Self-management is the materialisation of what occurs when you either act or do not act upon one's emotional response (Bradberry \& Greaves, 2009, pp. 32). Therefore, managing a business leader's internal states, resources and impulses can be instrumental in leading effective change in organisation as well as mobilising employees given the incidence of coronavirus pandemic, which impinges negatively on workers' sense of commitment, performance and motivation (Baba, 2021).

\section{Social-awareness}

Brown (2014) posits that social-awareness relates to an individual's ability to be cognisant of the emotions of other people when they occupy the same environment, and to become emotionally adept at understanding how someone else is feeling or thinking. Goleman et al. (2002) describe social awareness as empathy, a person's ability to attune themselves with how another person is feeling. Empathy has been defined as the process of understanding a person's subjective experience by vicariously sharing that experience while maintaining an observant stance (Zinn, 1993). The ability to empathise enables an individual to make emotional connections that resonate with another person, these connections according to Goleman et al (2002, pp. 49) initiate an unquestionable atmosphere which can create an aspirational sense of optimism about a better future. Empathy is considered a fundamental component within the context of social awareness (Goleman, 2002, pp. 50; Bradberry \& Greaves, 2009). The ability to develop a reciprocal relationship where one can be socially aware and empathise with other people, is today, a prerequisite condition of an effective relationship, as it guides behaviour and social effectiveness even in the context of Covd-19 challenges. Relationship management is another social competence (Goleman, 1995). A highly competent leader-follower cannot become competent if they are not adept at relationship-management (Bradberry \& Greaves, 2009, p 44).

\section{Relationship management}

This is one's ability to utilise and manage the awareness of other people's emotions as well as your own emotions to foster positive interactions and exchanges effectively. Relationship management poses a significant challenge with our social and professional lives and the ability to conquer or become more aware of our emotions within us and in others will enable individuals to put their emotional intelligence to work (Goleman et al, 2002, pp. 52). Taken together, the aspects of emotional intelligence presented in the preceding section are crucial to leading transformational change in organisation triggered by the Covid-19 pandemic, which will ensure that organisations, leaders and the led are triumphant as they re-set business for productivity and organisational effectiveness (Baba, 2021; Morońa \& Biolik-Moroń, 2021; Goleman, 2006). 


\section{Navigating the Coronavirus Pandemic: The Imperative of Leading with the Heart}

As argued by scholars (Bradberry \& Greaves, 2009; Goleman, 2006; 1995; Goleman et al, 2002) emotional intelligence has been described as a popular method of identifying transformational, effective leaders as well as a framework for nurturing effective leadership competences and skills (McKinsey, 2020; Salovey \& Mayer, 1997). The consensus on emotional intelligence literature suggests that a person's capacity to monitor, manage and control emotions in the context of oneself and others resonates with competency of transformational leadership. Hence, transformational leadership entails the activity that mobilises purposeful activity in a leader's followers by changing the method and processes in which they conceive and interpret the world around them (Morona et al., 2021). Accordingly, Sivanathan \& Fekken (2020) acknowledged that a leader's followers perceive leaders with a great capacity of emotional intelligence as more effective, persuasive and transformational leaders, which is needed in order to turn the corner in the era of coronavirus pandemic, when organisational leaders are required more than ever before to lead with the heart for genuine, lasting change (Baba, 2021).

In consonance with the above contention, Gardner \& Stough (2002) noted that a critical success factor for realising individualised consideration, which is a major facet of transformational leadership, is the ability of a leader to understand a follower's individualised needs and act accordingly (Bass, 1985). For example, the pandemic has changed employees' wellbeing, sense of commitment and motivation as some of them have anxiety of losing jobs and being made redundant or furloughed, which could impinge on their commitment, wellbeing and satisfaction at work (Morońa et al., 2021; Gardner \& Stough, 2002). Therefore, leading with the heart could propel a renewed (transformed) sense of commitment, inspiration and motivation that could be instrumental in navigating the coronavirus pandemic challenges as individualised needs and employment-related issues of employees would be taken into account. In this context, leading with the heart for change thus signals empathy and ability of a leader to manage relationships effectively for shared goal realisation (Kotter, 1990).

Accordingly, with emphasis on the ability to manage relationship effectively and empathy, (transformational) leaders, who have are emotionally intelligent are more likely to manifest individualised consideration. Additionally, emotional intelligence is linked to other aspects of transformational leadership including inspirational motivation, idealised consideration and intellectual stimulation (Gardner \& Stough, 2002), which could lead to win-win situation as opposed to transactional leadership that de-emphasises leading with the heart and rather foregrounds achieving organisational target (Babalola, Ren \& Ogbonnaya, 2020). In a recent study Babalola et al. (2020) have identified such leadership style that detracts from win-win dialectics as 'bottom-line mentality', a one-dimensional frame of mind revolving around bottom-line pursuits that permeates most contemporary organizations in the wake of COVI-19 challenges. They also found that the mentality of achieving target in the dark economic and business environment has triggered stress, insomnia and poor performance as employees are being managed rather than led. Additionally, they found that supervisors and leaders have through their leadership style and bottom-line mentality' exacerbated employee perceptions of a competitive climate that eventually intensifies employee thriving at work (Morona et al., 2021). Taken together, contemporary literature on the interface between emotional intelligence, transformational leadership and successfully navigating the roadblock of the COVI-19 challenges for business underpins the need for organisational leaders to be cautious of being too narrowly absorbed in bottom-line outcomes and aware of the broader implications of 'achieving target mentality' on disparate aspects of their employees' lives, which could be detrimental to organisational success - win-win dialectics (Babalola et al., 2020). 
In light of the above, the business world is overwhelmingly changing how organisations do business, but also how the business leaders lead (WHO, 2020). The Institute of Directors (IOD) stated that at this juncture business leaders must be able to demonstrate to their boards that they are taking heed of ensuing risks from the pandemic and taking appropriate steps to mitigate them within the context of effective leadership that resonates with the ideals of emotional, transformational leadership (Morońa et al., 2021). According to the International monetary fund (IMF, 2020) the global economy is projected to shrink sharply by three per cent during 2020 , much severer than during the 2008-09 financial crisis. The nature of the economic landscape post-2008 has been shrouded in a backdrop of volatility, uncertainty, complexity, and ambiguity, and this pervasive and fragile economic landscape has increased exponentially after the financial crisis of 2008 (WHO, 2020) till today.

As a result of the uncertainty and ambiguity thrown up by the coronavirus pandemic, the relationship between the leaders and followers has become fragile, topical and requires a type of leadership that leads with the heart not based on the algorithm of only financial gain at the expense of employee wellbeing, commitment and personal satisfaction. In taking this argument forward, Trimble (2020) has asserted that the contemporary world of business has shifted emphasis from command-and-control leadership style, which is more aligned to an autocratic and transactional leadership style to democratised, transformational and empowering leadership behaviours that espouse the ideals of showing emotion for collective gain (Goleman, 2006). Consequently, failure to align current leadership style to address the latter presents high risk of an employee feeling depressed, unproductive and demotivated, which may well tarnish the future working relationship as well as impinge on business sustainability and success after Covid-19 is gone as vaccines have been found lately (McKinsey, 2020).

\section{Conclusion}

As has been argued in the preceding sections, leadership is intrinsically an emotional process, whereby leaders recognise followers' emotional states, attempt to evoke emotions in followers, and then seek to manage followers' emotional states accordingly for organisational success and win-win situation. As has been contended here, the ability of leaders to influence the emotional climate can strongly influence performance, business sustainability, commitment and wellbeing, which are central to leading effective, transformational change in the coronavirus era and moving forward. As a result, this article has brought to limelight the centrality of emotional intelligence and transformational leadership in navigating the doldrums and business setbacks ushered in by the coronavirus pandemic for a better business world and societal health. It has also stressed the significance of reinvented leadership style that de-emphasises achieving target mentality through leading with the heart. Hence, in the current business environment, consumer behaviour has changed, leadership and management practices are in flux and there is a paradigm shift in business operationalisation, which requires effective leadership that is mediated by transformational and emotionally intelligent leadership, not leadership that is transactional and bereft of emotional base. In sum, it is within the spirit of this new-fangled organisational and leadership philosophy, which is being projected by this article, that organisations could transcend the trammels stemming from the coronavirus pandemic for a better business world and safer society.

\section{References}

1. Ammeter, P. A., Buckley, R. M., Douglas, C., Ferris, R. G. \& Prati, M. L. (2003). Emotional intelligence, leadership effectiveness, and team outcomes. The International Journal of Organisational Analysis, 11, 1, pp. 21-40. 
2. Averil, J. R. (1980). A constructivist view of emotion. In: Plutchik, R. \& H. Kellerman (Eds). Emotion: Theory, Research and Experience, 1, pp. 303-339.

3. Avolio, B. J. \& Bass, B. M. (1991). The full range of leadership development. Binghamton, NY: Bass, Avolio \& Associates.

4. Avolio, B. J., Bass, B. M., \& Jung, D. I. 1999. Re-examining the components of transformational and transactional leadership using the multifactor leadership questionnaire. Journal of Occupational and Organisational Psychology, 72, pp. 441-462.

5. Baba, M. M. (2020). Navigating COVID-19 with emotional intelligence. International Journal of Social Psychiatry, 66, 8, pp. 810-820.

6. Babalola, M. T., Ren, S. \& Ogbonnaya, C. (2020). Thriving at work but insomniac at home: Understanding the relationship between supervisor bottom-line mentality and employee functioning. Human Relation, Online First.

7. Bass, B. M. \& Avolio, B. J. (1990). The implications of transactional and transformational leadership for the individual, team, and organizational development. In: B. M. Staw \& L. L. Cummings (Eds.), Research in organisational change and development, 4, pp. 231-272. Greenwich, CT: JAI Press.

8. Bass, B. M. \& Avolio, B. J. (1993). Transformational leadership and organisational. Culture, Public Administration Quarterly, 17, 1, pp. 112-17.

9. Bass, B. M. (1985). Leadership and performance beyond expectations. New York: Harper \& Row.

10. Bennis, W. G. \& Nanus, B. (2004). Leaders: Strategies for taking charge. London: HapperCollins.

11. Bradberry, T. \& Greaves, J. (2009). Emotional intelligence 2.0. San Diego: Talent Smart.

12. Brown, C. (2014). The Effects of emotional intelligence (EI) and leadership style on sales performance. Economic Insights-Trends \& Challenges, 66, 3, pp.1-14.

13. Burns, J. M. (1978). Leadership. New York, NY: Harper.

14. Channer, P. \& Hope, T. (2001). The Emotionally Intelligent Leader. In Emotional Impact. London: Palgrave Macmillan, (pp. 25-26).

15. Cherniss, C. (2000). Emotional intelligence, what is it and what it matters? Paper presented at the annual meeting for the society of industrial-organisational psychology, New Orleans, LA April 15th, 2000 .

16. Chonko, B., Howell, D. R \& Bellinger, N. D. (1986). Congruence in salesforce evaluation: relation to sales perceptions of conflict and ambiguity. Journal of Personal Selling \& Sales,6, 1, pp. 35-47.

17. Fairholm, G. W. (1998). Leadership as an exercise in virtual reality. Leadership and Organisation Development Journal , 19, 4, pp. 187-193.

18. Gardner, H. (1983). Frames of mind: The theory of multiple intelligences. New York: Basic Books.

19. Gardner, L. \& Stough, C. K. K. (2002). Examining the relationship between leadership and emotional intelligence in senior level managers. Leadership \& Organisation Development Journal, 23, 2, pp. 68-78.

20. George, J. M. (2000). Emotions and leadership; the role of emotional intelligence. Human Relations, 53, pp. 190-210.

21. Goleman, D. (2006). Social Intelligence: The new science of human relationships. London: Arrow Books.

22. Goleman, D. (1995). Emotional Intelligence: Why it can matter more than IQ. London: Bloomsbury.

23. Goleman, D., Boyatzis, R. \& McKee, A. (2002). Primal Leadership Learning to Lead with Emotional Intelligence. Boston, Massachusetts: Harvard Business Press.

24. Howell JM, Avolio BJ. (1993) Transformational leadership, transactional leadership, locus of control, and support for innovations: key predictors of consolidated-business-unit performance. Journal of Applied Psychology, 78, 6, pp. 891- 903.

25. Howell, J. \& Hall-Merenda, K. (1999). The ties that bind: The impact of leader-member exchange, transformational and transactional leadership, and distance on predicting follower performance. Journal of Applied Psychology, 84, 680-694.

26. Humphrey, R. H. (2002). The many faces of emotional leadership. The Leadership Quarterly, 13, 5, pp. 493-504.

27. Kotter, J. (1990). A force for change. New York: Free Press.

28. Logan, D., King, J. \& Fischer-Wright, H. (2008). Tribal leadership. London: Collins.

29. London, M., (1999). Principled leadership and business diplomacy. Journal of Management Development, 18, 2 p170-92.

30. Mathews, G., Zeidner, M., \& Roberts, R. D. (2002). Emotional intelligence: Science and myth. Cambridge, MA: MIT Press. 
31. McKinsey. (2020). COVID-19: Implications for business. www.mckinsey.com > risk > our-insights > covid-19-im... (Accessed 23/11/2020).

32. McNaughton, N. \& Zubairi, M. S. (2014). Emotional intelligence: convinced or lulled? Medical Education, 48, PP. 456-465.

33. Morońa, M. \& Biolik-Moroń, M. (2021). Trait emotional intelligence and emotional experiences during the COVID19 pandemic outbreak in Poland: A daily diary study. Personality and Individual Differences, 168, 110348, pp.1-12.

34. Northouse, P. G. (2007). Leadership: theory and practice. London: Sage.

35. Nwagbara, U. (2012). En/Countering Corrupt Leadership and Poor Corporate Governance in the Nigerian Banking Sector: Towards a Model of Ethical Leadership. Indian Journal of Corporate Governance, 5, 2, pp. 133-148.

36. Ogbonna, E. \& Harris, C. L. (2000). Leadership style, organisational culture and performance: Empirical evidence from UK companies. International Journal of Human resources Management, 11, 4 766-788.

37. Podoff, P. M., Todor, W. D., \& Skov, R. (1982). Effects of leader contingent and non-contingent reward and punishment behaviors on subordinate performance and satisfaction. Academy of Management Journal, 25, 4, 810-821.

38. Podsakoff, M. P., Moorman, H. R \& Fette, R. (1990). Transformational leader behaviours and their effects on followers. Trust in Leader satisfaction and organizational citizenship behaviour. Leadership Quarterly, 1, 2, pp. 107-142.

39. Polychroniou, V. P. (2009). Relationship between emotional intelligence and transformational leadership supervisors: The impact of team effectiveness. Team performance management, 15, 7/8, pp. 343-356.

40. Rost, J. C. (1991). Leadership for the Twenty-first Century. London: Greenwood Publishing Group.

41. Ruiu, M. L., Ragnedda, M. \& Ruiu, G. (2020). Similarities and differences in managing the Covid19 crisis and climate change risk. Journal of Knowledge Management, 24, 10, pp. 2597-2614.

42. Sahu, P. (2020). Closure of universities due to coronavirus disease 2019 (COVID-19): Impact on education and mental health of students and academic staff. Cureus, 12, 4, pp.1-6.

43. Salovey, P. \& Mayer, J.D. (1990). Emotional intelligence, imagination. Cognition and Personality, 9, pp. 185-211.

44. Sivanathan, N. \& Fekken, C. (2020). Emotional intelligence and transformational leadershipLeadership \& Organization Development Journal, 23, 4, pp.198-204.

45. Thorndike, E. L. (1920). Intelligence and its uses. Harper's Magazine, 140, pp. 227-235.

46. Trimble, A., 2020. The impact of Covid-19 on working relationships. [Online] Available at: https://www.kingsfund.org.uk/blog/2020/05/impact-covid-19-working-relationships [Accessed 12th June 2020].

47. UNESCO. (2020). COVID-19 Educational disruption and response. Retrieved March 25, 2020, from https://en.unesco.org/themes/education-emergencies/coronavirus-school-closures.

48. Vera, D. \& Crossan, M. (2004). Strategic leadership and organisational learning. Academy of Management Review, 29, 2, pp. 222-240.

49. WHO. (2020). Coronavirus disease (COVID-19) pandemic. Retrieved March 20, 2020, from https:// www.who.int/emergencies/diseases/novel-coronavirus-2019.

50. Yammarino, F. J. \& Bass, B. M. (1990). Transformational leadership and multiple levels of analysis. Human Relations, 43, 975-995.

51. Yukl, G. A. \& van Fleet, D. D. (1992). Theory and research on leadership in organisations. In: Handbook of industrial \& organisational psychology, 147-197. California: Consulting Psychologists Press.

52. Yukl, G. A. (1994). Leadership in organisations. (3rd ed.). Englewood Cliffs, New Jersey: PrenticeHall.

53. Zeidner, M., Matthews, G. \& Roberts, R. D. (2004). Emotional intelligence in the workplace: A critical review. Applied Psychology, 53, 3, pp.371-399.

54. Zinn, W. (1993). The empathetic physician. Archives of Internal Medicine, 153, pp. 306-312. 